\title{
LABORATORY STUDIES ON THE POSSIBILITY OF CULEX QUINQUEFASCIATUS TO HARBOR HEPATOZOON SP. INFECTING CERASTES CERASTES CERASTES VIPER IN EGYPT By
}

\author{
NAGWA A. RASHDAN, FATMA H. GALAL AND ALAA F. GAD-ALLAH \\ Department of Entomology, Faculty of Science, Cairo University, Giza 12211, Egypt \\ Abstract
}

A successful experimental infection of Culex quinquefasciatus with Hepatozoon sp. infecting Cerastes cerastes cerastes viper was carried out under laboratory conditions of $24 \pm$ $3 \mathrm{C}$ and $60-70 \%$ R.H..The period monitored for complete sporogonic cycle was 21 days. The effect of high parasitimic blood meal was nonsignificant $(\mathrm{P}>0.05)$ on preoviposition period and hatchability. Meanwhile a highly significant reduction was observed in oviposition rate, number of deposited eggs, number of hatched larvae and longevity $(\mathrm{P}<0.01)$. On the contrary moderate infection with Hepatozoon revealed a great significant increase in fecundity $(\mathrm{P}<0.01)$ and a nonsignificant decrease in longevity $(\mathrm{P}>0.05)$.

Key words: Experimental, Culex quinquefasciatus, Hepatozoon sp, Cerastes Cerastes Cerastes

\section{Introduction}

Mosquitoes were incriminated since ancient times in the transmission of vertebrate diseases. Culex quinquefasciatus is a vector of many pathogens of humans, and both domestic and wild animals. This species include WNV, SLEV and Western equine encephalitis virus (WEEV), the main vector of SLEV in the southern U.S. (CDC, 2012), Reticuloendotheliosis virus (Ho-lder et al, 1999), filarial worm Wuchereria bancrofti (Agrawal and Sashindran, 2006) and the protozoa Hepatozoon which is responsible for hepatozoonosis disease (Rashdan, 2007).

This study investigated the possibility of C. quinquefasciatus to harbor Hepatozoon sp. infecting the Egyptian viper Cerastes cerastes cerastes and to detect the influence of infection on some biological aspects of the mosquito host.

\section{Materials and Methods}

Culex quinquefasciatus was initially collected from Borg El Arab area, Alexandria Governorate and colonized in the laboratory of Entomology Department, Cairo University. Rearing technique was carried out according to Adham et al. (2003). Wild caught vipers Cerastes cerastes cerastes were obtained from Aswan Governorate. Each viper was housed in a specific mesh screened wooden cage under laboratory conditions of
$24 \pm 3 \mathrm{C}$ and $60-70 \%$ R.H., and was provided with constant access of water and maintained on a diet of mice each week. Parasite detection inside the vipers was carried out according to Bashtar et al. (1984) and parasitaemia percent was calculated (Galal (2010). Mosquito infection and sporogony detection were according to Rashdan and El Sebaii (2006).

For studying the reproductive capacity, longevity and mortality assessment of Culex quinquefasciatus females infected with Hepatozoon sp. from the viper Cerastes cerastes cerastes three groups, 50 females each, of 3-4-day old were starved for $12 \mathrm{hrs}$ prior to feeding. One mosquito group (G1) was allowed to feed on non-infected viper. The second group (G2) was allowed to feed on naturally infected viper with moderate parasitaemia (3-10\%). The third group (G3) was offered naturally infected viper with high parasitaemia (11-20\%). Engorged females from each group were kept separately and examined daily for preoviposition period, number of deposited eggs, percent hatchability, oviposition rate together with longevity. The experiment was repeated three times.

\section{Results}

The results are shown in table (1) and figure (1) 
Table 1: Effect of Hepatozoon sp. infection on reproductive capacity and longevity of Culex quinquefasciatus females

\begin{tabular}{|c|c|c|c|c|c|c|c|c|c|c|c|c|}
\hline \multirow{3}{*}{$\begin{array}{c}\text { Exper } \\
\text { iment } \\
\text { al } \\
\text { femal } \\
\text { es }\end{array}$} & \multicolumn{2}{|c|}{$\begin{array}{l}\text { Preoviposition } \\
\text { period (days) }\end{array}$} & \multicolumn{2}{|c|}{$\begin{array}{c}\text { Oviposition rate } \\
(\%)\end{array}$} & \multicolumn{2}{|c|}{$\begin{array}{l}\text { No. of deposited } \\
\text { eggs }\end{array}$} & \multicolumn{2}{|c|}{$\begin{array}{c}\text { No. of } \\
\text { hatched larvae }\end{array}$} & \multicolumn{2}{|c|}{$\begin{array}{l}\text { Hatchability } \\
\text { percentage }\end{array}$} & \multicolumn{2}{|c|}{$\begin{array}{c}\text { Longevity } \\
\text { (days) }\end{array}$} \\
\hline & Min. & Max. & Min. & Max. & Min. & Max. & Min. & Max. & Min. & Max. & Min. & Max. \\
\hline & \multicolumn{2}{|c|}{ Mean \pm S.E } & \multicolumn{2}{|c|}{ Mean \pm S.E } & \multicolumn{2}{|c|}{ Mean \pm S.E } & \multicolumn{2}{|c|}{ Mean \pm S.E } & \multicolumn{2}{|c|}{ Mean \pm S.E } & \multicolumn{2}{|c|}{ Mean \pm S.E } \\
\hline \multirow{2}{*}{ G1 } & 3.00 & 22.00 & 90.91 & 100.00 & 47.00 & 284.00 & 44.00 & 127.00 & 39.08 & 100.00 & 8.00 & 40.00 \\
\hline & \multicolumn{2}{|c|}{$\begin{array}{c}12.06 \pm 1.55 \\
\mathrm{~A}\end{array}$} & \multicolumn{2}{|c|}{$\begin{array}{c}94.41 \pm 4.81 \\
\mathrm{~A}\end{array}$} & \multicolumn{2}{|c|}{$\begin{array}{c}123.29 \pm 10.00 \\
\mathrm{~B}\end{array}$} & \multicolumn{2}{|c|}{$\begin{array}{c}86.76 \pm 5.72 \\
B\end{array}$} & \multicolumn{2}{|c|}{$\begin{array}{c}76.30 \pm 4.21 \\
\mathrm{~A}\end{array}$} & \multicolumn{2}{|c|}{$\begin{array}{c}28.22 \pm 1.74 \\
\mathrm{~A}\end{array}$} \\
\hline \multirow{2}{*}{ G2 } & 5.00 & 24.00 & 40.00 & 90.00 & 77.00 & 225.00 & 59.00 & 215.00 & 59.69 & 97.73 & 1.00 & 48.00 \\
\hline & \multicolumn{2}{|c|}{$\begin{array}{c}13.18 \pm 1.95 \\
\mathrm{~A}\end{array}$} & \multicolumn{2}{|c|}{$\begin{array}{c}60.00 \pm 12.25 * * \\
\text { B }\end{array}$} & \multicolumn{2}{|c|}{$\begin{array}{c}173.75 \pm 12.67 * * \\
\mathrm{~A}\end{array}$} & \multicolumn{2}{|c|}{$\begin{array}{c}142.08 \pm 13.25^{* *} \\
\mathrm{~A}\end{array}$} & \multicolumn{2}{|c|}{$\begin{array}{c}80.99 \pm 2.86 \\
\mathrm{~A}\end{array}$} & \multicolumn{2}{|c|}{$\begin{array}{c}24.50 \pm 2.02 * * \\
\mathrm{~A} \\
\end{array}$} \\
\hline \multirow{2}{*}{ G3 } & 4.00 & 9.00 & 20.00 & 50.00 & 57.00 & 142.00 & 4.00 & 116.00 & 6.78 & 95.77 & 1.00 & 16.00 \\
\hline & \multicolumn{2}{|c|}{$\begin{array}{c}6.33 \pm 1.45 \\
\mathrm{~A}\end{array}$} & \multicolumn{2}{|c|}{$\begin{array}{c}40.00 \pm 7.07 * * \\
\text { B }\end{array}$} & \multicolumn{2}{|c|}{$\begin{array}{c}90.20 \pm 9.48^{* *} \\
\mathrm{~B}\end{array}$} & \multicolumn{2}{|c|}{$\begin{array}{c}65.60 \pm 11.32 * * \\
\mathrm{~B}\end{array}$} & \multicolumn{2}{|c|}{$\begin{array}{c}69.51 \pm 9.54 \\
\mathrm{~A}\end{array}$} & \multicolumn{2}{|c|}{$\begin{array}{c}9.00 \pm 1.93 * * \\
\text { B }\end{array}$} \\
\hline
\end{tabular}

G1: females fed on non-infected viper, G2: females fed on infected viper with moderate parasitaemia, G3: females fed on infected viper with high parasitaemia, $\mathrm{P}<0.05^{*}=$ significant, $\mathrm{P}<0.01^{* *}=$ highly significant, same letter means not significant.

\section{Discussion}

In the present study, smears from both infected groups of $C$. quinquefasciatus females showed the developmental stages appearance of the Hepatozoon parasite. Females reared under $24 \pm 3^{\circ} \mathrm{C}$ and $60-70 \% \mathrm{RH}$ showed complete gamogony and sporogony (Fig. 1). Zygote formation started by day 4 post infection. This result agreed with Bashtar et al. (1987) for H. gracilis and Fayed et al. (1995) for H. malpoloni but, disagreed with that obtained by Bashtar et al. (1984) for $H$. aegypti. Infected females gave rise to mature sporozoites by day 21 post infection. This result more or less agreed with the sporogonic period reported by Rashdan et al. (2006) for $H$. sp. harbored by Uromastyx microlepis. Meanwhile different periods of sporogonic cycle was observed by Abdel Ghaffar et al. (1994) for H. ghaffari; Smith et al. (1994) for H. sipedon; Fayed et al. (1995) for H. malpoloni; Desser et al. (1995) for $H$. catesbiance; Kim et al. (1998) for $H$. clamatae and Ebraheem et al. (2006) for $H$. matruhensis.

In the present study, $C$. quinquefasciatus females fed on the viper $C$. cerastes cerastes with high parasitaemia of Hepatozoon reduced the preoviposition period and hatchability percent non-significantly $(\mathrm{P}>0.05)$. The reduction was great and highly significant $(\mathrm{P}<0.01)$ in oviposition rate, number of deposited eggs and number of hatched larvae. This result agreed with Hogg and Hurd (1995) for Anopheles stephensi infected with
Plasmodium yoelii nigeriensis at high oocyst burdens and by Galal (2010) in case of $C$. (C.) pipiens fed on highly infected skinks with $H$. gracilis.

Using a viper with moderate Hepatozoon infection showed a non-significant increase in the preoviposition period $(\mathrm{P}>0.05)$. This result agreed with that recorded by Ebraheem et al. (2006) in case of $C$. pipiens infected with $H$. maturhensis and with Rashdan et al. (2006) in case of C. quinquefasciatus and $C$. pipiens infected with Hepatozoon sp. Meanwhile, a highly significant reduction in oviposition rate together with a highly significant increase in number of deposited eggs and number of hatched larvae was obtained $(\mathrm{P}<0.01)$. This finding agreed with Ferguson et al. (2003) who reported the increase of fecundity of infected mosquitoes with malaria. On the contrary, reduction in fecundity was reported by Hogg and Hurd (1997) for Anopheles gambiae infected with malaria; Adham et al. (2003) for C. pipiens infected with $H$. gracilis, Ebraheem et al. (2006) for $C$. pipiens infected with $H$. maturhensis and Rashdan et al. (2006) for C. pipiens and $C$. quinquefasciatus infected with Hepatozoon sp.

The hatchability percent was non-significantly affected by the presence of Hepatozoon sp. within female mosquitoes. This result agreed with that reported by Adham et al. (2003) for $C$. pipiens infected with $H$. gracilis, Ebraheem et al. (2006) for $C$. pipiens infected with $H$. maturhensis, Rash- 
dan et al. (2006) for C. quinquefasciatus and C. pipiens infected with Hepatozoon sp. and Rashdan and El-Sebaii (2006) for C. neavei infected with $H$. maturhensis.

Longevity severely reduced when females were fed on infected viper with high parasitaemia to $9 \pm 1.93$ days in average $(\mathrm{P}<0.01)$. This result agreed with Galal (2010) in case of $C$. (C.) pipiens infected with $H$. gracilis. By using moderate parasitaemic viper there was a non-significant decrease in longevity of C. quinquefasciatus females $(\mathrm{P}>0.05)$. This data agreed with Adham et al. (2003) in case of $C$. pipiens females infected with $H$. gracilis, Ebraheem et al. (2006) in case of $C$. (C.) pipiens females infected with $H$. matruhensis, Rashdan et al. (2006) in case of $C$. pipiens and $C$. quinquefasciatus infected with Hepatozoon sp. But, Galal (2010) reported a significant increase in longevity of $C$. (C.) pipiens infected with $H$. gracilis.

\section{Conclusion}

Members of Hepatozoon possess particularly complex life cycles which vary considerably among species. Appearance of complete sporogonic developmental stages of Hepatozoon infecting Cerastis cerastis cerastis together with the increase of the biological parameters of female C. quinquefasciatus infected with moderate parasitaemia showing the adaptation of the mosquito towards Hepatozoon infection that confirm the ability of $C$. quinquefasciatus to be a good vector of Hepatozoon sp.

\section{References}

Abdel Ghaffar, F, Abdel Aziz, A, El-Toukhy, A, Abdel Gawad, M, 1994: Light and Electron microscopic studies on blood stages and merogony of Haemogrerarina sp. infecting the gecko, Ptyodactylus hasselquisti. J. Egypt. Ger. Soc. Zool. 14: 341-63.

Adham, FK, Gabre, RM, Ayaad, TH, Galal, F H, 2003: The effects of laboratory Hepatozoon gracilis infection on the fecundity, mortality and longevity of Culex (C.) pipiens Linnaeus (Diptera: Culicidae) in Egypt. J. Egypt Soc. Parasitol. 33, 2:353-60.

Agrawal, VK, Sashindran VK, 2006: Lymphatic filariasis in India: Problems, challenges and new initiatives. India Med. J. Armed Forces 62:359-62.

Bashtar, AR, Abdel-Ghaffar, FA, Mehlhorn, H, 1984: Hepatozoon aegypti nov.sp 3- Electron microscope studies on the gamogony and sporogony inside the vector, Culex pipiens molestus. Z. Parasitenkund. 70:53-65.

Bashtar, AR, Abdel-Ghaffar, FA, Shazly, MA, 1987: Developmental stages of Hepatozoon gracilis (Wenyon, 1909) comb. nov.: A parasite of the Egyptian skink, Mabuya quinquetaeniata. J. Parasitol. Res. 73:507-14.

CDC, 2012: Saint Louis Encephalitis, USA.

Desser, SS, Hong, H, Martin, DS, 1995: The life history, ultrastructure and experimental transmission of Hepatozoon catesbianae $\mathrm{n}$. comb., an api-complexan parasite of the bullfrog, Rana cates-beiana and the mosquito Culex territans in Algonquin Park, Ontario. J. Parasitol. 81:212-22.

Ebraheem, MH, Rashdan, NA, Fayed, HM, Ga-lal, FH, 2006: Laboratory studies on the possibility of Culex (culex) pipiens L. to harbor and transmit Hepatozoon matruhensis to the Egyptian snake Pasmmophis schokari. J. Egypt. Soc. Parasitol. 36, 1:241-50.

Fayed, HM, Sakran, TF, El-Tokhy, AA, Ahmed, AK, 1995: Developmental stages of Hepatozoon malpoloni (Ramadan, 1974) comb. nov. infecting the Egyptian snake Malpolon monspesulanus insi-gnitus (Geoffroy). J. Egypt. Ger. Soc. Zool. 16, D: 1-24.

Ferguson, HM, Rivero, A, Read, AF, 2003: The influence of malaria parasite genetic diversity and anemia on mosquito feeding and fecundity. J. Parasitol.127:9-19.

Galal, FH, 2010: Effect of the intensity of Hepatozoon gracilis parasitaemia on some biological aspects of Culex (culex) pipiens (Diptera: Culici-dae). Acad. J. Biol. Sci. 3, 1:57- 66.

Hogg, JC, Hurd, H, 1995: Plasmodium yoelii nigeriensis: The effect of high and low intensity of infection upon the egg production and blood meal size of Anopheles stephensi during three gonotro-phic cycles. J. Parasitol. 111:555-62.

Hogg, JC, Hurd, H, 1997: The effects of natural Plasmodium falciparum infection on the fecundity and mortality of Anopheles gambiae s. I. in north east Tanzania. J. Parasitol. 114:325-31.

Holder, P, Browne, G, Bullians, M, 1999: The mosquitoes of New Zealand and their animal disease significance. Surveillance 26, 4:12-5. 
Kim, B, Smith, TG, Desser, SS, 1998: The life history and host specificity of Hepatozoon clamatae (Apicomplexa: Adeleorina) and ITS-1 nucleotide sequence variation of Hepatozoon species of frogs and mosquitoes from Ontario. J. Parasitol. 84, 4:789-97.

Rashdan, NA, 2007: The infective capacity of Culex quinquefasciatus Say in the transmission of Hepatozoon sp. parasitizing Uromastyx microlepis lizard. J. Egypt. Ger. Soc. Zool. 52, E: 317.

Rashdan, NA, El-Sebaii, SE, 2006: Culex neavei Theobald, as a possible transmitter of Psammophis schokari. J. Egypt. Soc. Parasitol. 36, 1:1-6.

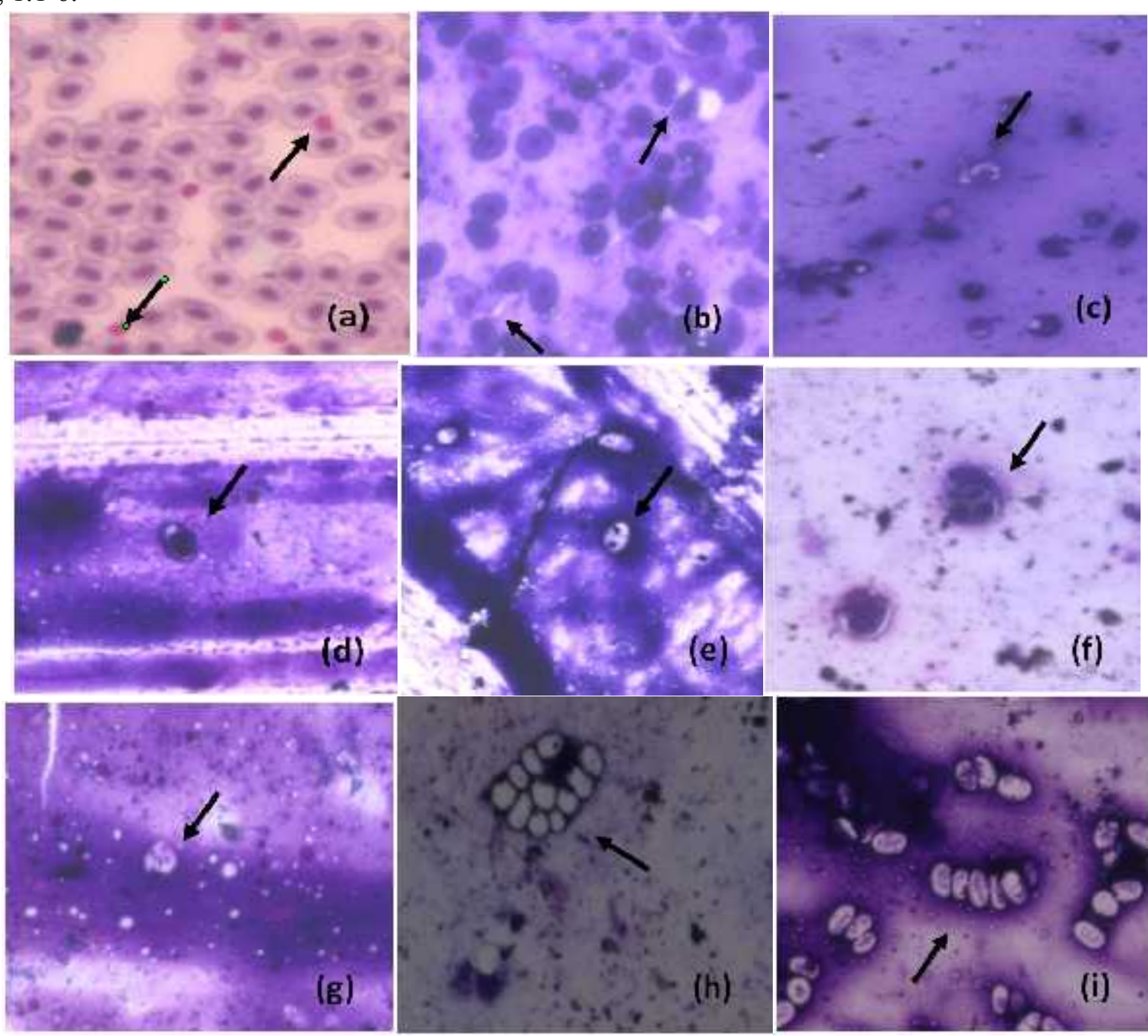

Fig.1: Sporogonic cycle of Hepatozoon sp. inside mosquito host. a: gametocytes inside viper RBCs, b: free gametocytes, c:micro-and macrogametes, d:mononucleated zygote, e:binucleated zygote, f:tetranucleated zygote, g: oocyst, h:sporoblast, i: sporocysts with mature sporozoites
Rashdan, NA, El-Sebaii, SE, Al-Khalifa, K, 2006: Studies on some biological aspects of Culex pipiens and Culex quinquefasciatus (Diptera: Culicidae) infected with Hepatozoon sp. harbored by the Saudian lizard Uromastyx microlepis. J. Egypt. Soc. Parasitol. 36, 1:251-8.

Smith, TG, Desser, SS, Martin, DS 1994: development of Hepatozoon sipedon sp. nov. (Apicomplexa: Adeleina: Hepatozoidae) in its natural host, the Northern water snake (Nerodia sipedon sipedon), in the culicine vectors Culex pipiens and $C x$. territans \& in an intermediate host, the Northern leopard frog (Rana pipiens). Parasitol. Res. 80, 7:559-68 